\title{
INVESTIGATING IRAQI EFL LEARNERS' ATTITUDES TOWARD USING DIGITAL KAHOOT GAMES AND ITS IMPACT ON CREATING ACTIVE LEARNING
}

\author{
Asst instructor :Zinah Majeed Hameed \\ College of Basic Education, Al-Mustansiryah University, Iraq
}

DOI: $10.37648 /$ ijrssh.v10i02.011

Received:10 ${ }^{\text {th }}$ January, 2020; Accepted:04 ${ }^{\text {th }}$ February, 2020; Published: $24^{\text {th }}$ February, 2020

\begin{abstract}
Kahoot is a set of questions on certain topics. The questions are prepared by teachers and students, by users in society and by business people. The questions are asked to a large number of people in the society, who are the 'players'. They are asked in real time, and they lead to the creation of a fun and learn environment. All the participants are part of the game.

This study aims at Investigating Iraqi EFL Learners' Attitudes toward Using Digital Kahoot games and the impact of its use on the learning environment. The study is restricted to third-year college learners of the English language in Misan Governorate during the second term of the academic year 2018-2019. In all, 40 students, both male and female participated in the study. A questionnaire was administered to the participants and the conclusion is based on their responses to the questions. The obtained results indicate the weighted mean $90 \%$ as items that gain low effectiveness from advance learners. Consequently, four items gained most positive effectiveness, that is 100\%

Key words: Digital Kahoot Games, players, video. media

\section{INTRODUCTION}

\subsection{The Problem of the Study and its Significance}

English as a compulsory subject consists of all four language skills, namely, listening, speaking, reading and writing. To improve the skills, students must achieve proficieny in each area. This implies active learning on their part. Reading is an important skill in the academic firld esprcially at the university level. Proficiency in reading comprehension promotes academics and scholarship (Ching \& Hui, 2013; Huckin, Haynes, \& Coady, 1993). It is necessary for teachers to make use of appropriate media to improve

the language skills of EFL students. Media are the means of communication through which concepts are transferred to students; they are the vehicles for formatting, storing and transferring instructions or concepts or concepts to learners(Schwen, 1977).

According to Oswalt (2010) there are four types of media:

(1) Print Media: They are print based and include books, magazines, newspapers, comics and graphic novels. They belong to past times when no other alternatives were available. Print media are exclusively visual.
\end{abstract}


(2) Television: Television is becoming increasingly popular all over the world and has entertained Americans for more than fifty years. The number of channels and special programmes is in thousands today and cater to the interests of all, young and old. There are all types of programmes to choose from. Television is an audio-visual medium.

(3) Movies or films, are the oldest form of motion picture technology. Movies are an entertaining, influential and effective way that capture life-like videos. Initially people had to visit theatres to watch movies, but nowadays, when technology is rampant, movies can be viwed on computers, tablets or even cell phones.

(4)Video games: They were introduced in the 1980s and are gaining increasing popilarity, particularly among youth. The face of today's games has up to date features like advanced graphics, three-dimansional display, realistic landsacpes and advanced simulations. One can compete with other players from any location through networking. Modern video games are exciting, attractive and interactive. Players enjoy realistic experience because of graphics. Players get a feeling that theyare immersed in the game. (Ibid).

The reesaercher explored the possibility of combining a type of media like video games with another modern online game called kahoot. The study deals with the effectiveness of applying kahoot games in order $t$ provide a creative and active learning environment.

Strommen (1992) points out that it is difficult to merge the fun involved in technology assessment and the engaging interactive test and yet maintain the seriousness in evaluation. Howver, in future the enhancement of technology-based assessment such as Kahoot application can be modified by focusing on students' dialogue with lecturers, clear objectives, and quality of information delivered in the test. The present study tries to find out whether there is a positive response from students towards kahoot games and how far these games can promote learning. If the repsonses are negative, there might be some problem which can be investigated and solved in future (Harmer 2003:70).

\subsection{Aim of the study}

- To investigate Iraqi EFL students' attitude towards using digital kahoot games and its impact on creative active learning.

\subsection{Limits}

1.The study is limited to the third-year students at the Department of English /College of Education/University of Maisan

2. The study is limited to the effectiveness of using kahoot in creating active learning.

\subsection{Value of the study}

The study will be valuable in explaining the the purpose of using kahoot games and evaluating their effectiveness. The study will also investigate the perception of students towards the games for the purpose of bringing about creative active learning. In this age of technology, it is necessary to implement technology based learning methods and materials and understand their worth. An understanding of the problems will enable researchers to make modifications and changes as necessary. The experiment is carried out on students and the aim is to understand their perspective and attitude. It is always beneficla when the target is the group on which the games are implemented.

\section{THEORETICAL BACKGROUND}

\subsection{What is Meant by Kahoot?}

Kahoot is a quiz game which is a common type of games. The difference is that this is an internet game. It is generally played in social settings but can also be played in classrooms and used for the purpose of learning. It permits players not only to participate but to create their own quizzes and share them with other players in the group.

It was created in August 2013 in Norway. It is suitable for use in a classroom because participants sit in front of a large screen and the quiz is displayed on a big 
screen in front of them. A projector is used for the game.

At the beginning of the game, each player joins in by using a personal device and logging in by setting a nickname. The host then presents the questions in the quiz and multiple answers. The participants select the correct answer. The questions and the answers are displayed on the screen. The naswers are entered on their devices by each participant. The device can be a tablet, a laptop or a cell phone. (Larson, 2010:17). The time for responding to each question is pre-set. When all the players respond to all questions, the answers are displayed on the screen and alos the names of ccorrect responders. The players continue to answer the multiple choice questions and the number of correct responses lead them to the top of the leadersboard.

In this way, kahoot has proved to be an interesting and engaging, interactive learning tool that can be used in a classroom. The role of the lecturers is limited. A large number of players can participate at a given time. It is a self-learning tool. All that the players have to do is to press the button and respond to the question. It is useful in higer education since it provides metacognitive support. It is a free online platform. It is user friendly and user centered. There are about 30 million users worldwide. It is a modern educational technology and uses game based pedagogy. It has a lot of potential as it can also be used for online research support to students, preparation of questionnaires discussion sessions or evaluation (Latief, 2011:95).

The students are awarded points for the correct responses. This keeps them motivated. The activity can be well prepared in advance. Students play along willingly with others. They find it meaningful and purposeful.

Hence, the procedure for joining kahoot is simple. Quizzes can be created with an interface designe din English. Only teachers can log in to 'getkahoot.com' in order to create games and a game environment. It is not necessary for students to sign in. It is a free program and accessible to all (Huckabee and Bissette :2014).

Caglar ( 2017) states that the program can be easily formed by signing in and the games can be shared and viwed with other players. For classroom use, teachers can select approved kahoot games. Future study questions equivalent to classroom lecture notes can be prepared by Kahoot. Students can sign up by using their nickname which appear on the screen, thus motivating them. They participate more actively. They experience a sense of involvement and the game is played in real time, making it all the more interesting. Students need not download the application, which is an added advantage.

The kahoot program allows integration of several media like videos, music, sound, photographs etc. an environment conducive to classroom discussion can be created in a short time. Of course, there are a few shortcomings. For example, one must have a wi-fi connection; the games cannot be played offline. Interruption in the internet connection can cause communication gaps. Students might end up getting frustrated if this happens too often. The following steps have to be followed for signing up and participating in the game:

1. Create a free account on getkahoot.com

2. Choose the option from quiz, discussion or survey. The quiz is assigned a name. The user returns to the homescreen and answers the questions asked in the quiz (Sera and Wheeler,2017:26).

3.Questions (+add question on the bottom right) and answers (incorrect under the right answer should be changed to correct) are added. After adding questions, the time is set and settings then clicked on.

4. The language and primary audience sections are selected and cover image is clicked. Choosing a cover photo is optional.

5. The quiz is ready to be taken after clicking 'done'.( Werbach andHunter ,2012).

\section{2 . Types of Kahoot}

\section{Quiz :}

This is the most common and widely used kahoot, integrating the game based pedagogy in traditional learning and leading to blended learning that integrates technology and conventional pedagogy. Any number of questions can beincluded in aquiz. There is no 
limitation. A related picture or video can accompany the question as a trigger or scaffold. There are 2-4 multiple choice answers. There must be at least one correct answer (but more can be chosen), and the time limit for each question can be individually set from 5 seconds to 2 minutes, depending upon the difficulty level. An entire room filled with students can be engaged at a time and the knowledge of each playes can be assessed at the individual level. The game can be adapted to the learning style of each player accordingly. It is also possible to track the progress of the players over time.

Learners can be inspired to create their own quizzes. They should also be inspired to give correct answers and score maximum number of points. The speed of response also matters; faster the answers, more the points. Intermittently, the top five scoreres' names are displayed on the leaderboard which makes them feel proud. The ultimate winner is announced ta the end. The answers of each individual player can be checked by downloading them later, if they are interested.

\section{Discussion}
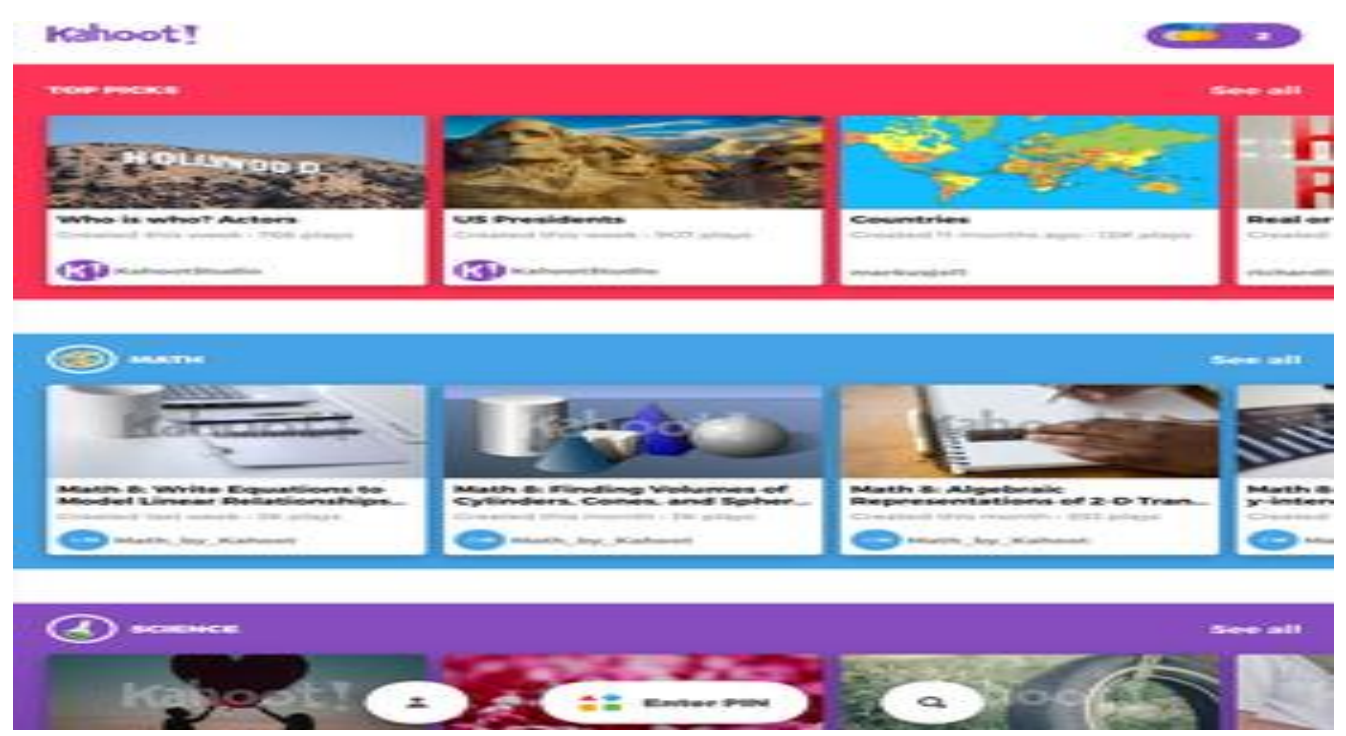


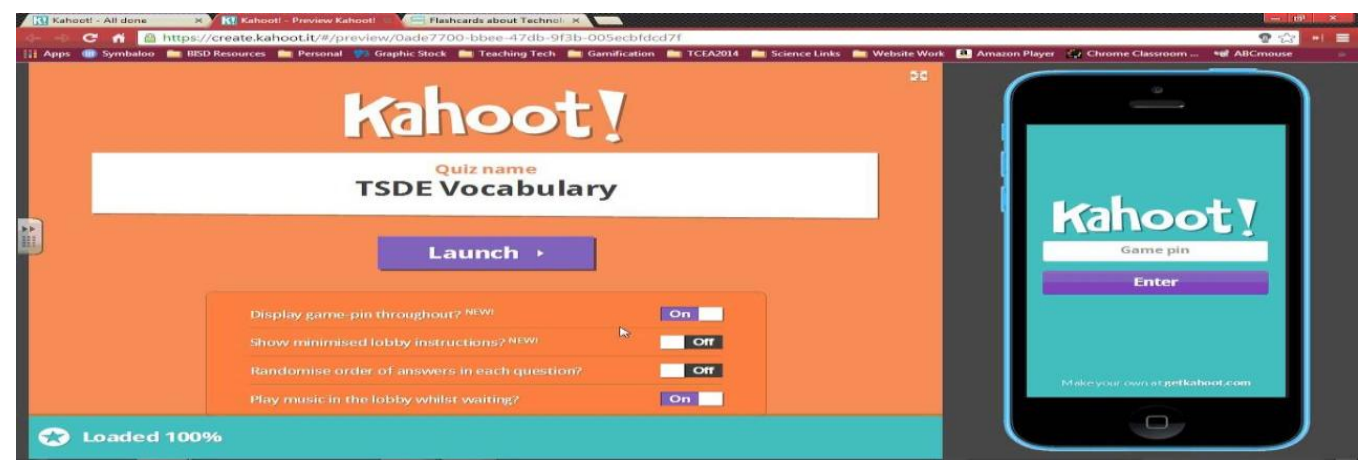

Figure $(1,2)$ about kahoot Pictures

\section{METHODOLOGY}

\subsection{Population and Sample}

The sample of this study includes (40) Students of the third stage Department of English Language at the College of Education, University of Misan. The total number of the College students' population is 133. It is a mixed sample consisting of nboth male and female students.

\section{2 . Instruments}

In order to gain information about the EFL College students' opinions about the effect of using Kahoot games in creating active learning, the appropriate instrument, that is a questionanaire has been constructed.

\subsubsection{Face Validity}

Face validity is secured if the items appear to be measuring what is intended to be measured (Ebel ,1972:78). The questionnaire was reviewed by experts in the fields of linguistics as well as education and EFL. The final version after changes and modifications consisted of 20 questions. It was distributed to the sample selected in order to gain their opinion regarding the use of kahoot games in creative active learning.

\subsubsection{Pilot Administration}

After ensuring the validity of the questionnaire, a pilot version was administered to a sample of 20 College students randomly selected from Colleges of Education at University of Misan.it was found in the pilot study that students required minimum 40 minutes to complete the questionnaire.

\subsubsection{Reliability}

Reliability refers to how consistent evaluation results are from one measurement to another (Grolund, 1976:102).

\subsubsection{Scoring Scheme}

Accurate scoring procedures should be adopted in order to get proper results to ensure objectivity and reliability (Harrocks \& Schannover, 1968:76).

In order to achieve the aim of the study, the questionnaire is intended to be answered according to a 4 points scale (Satisfied, neutral, Unsatisfied, and Very satisfied). The marks are assigned as follows:

- Unsatisfied - 1 mark

- Neutral-2 marks

- Satisfied - 3 marks

- Very satisfied 4 marks 
(IJRSSH) 2020, Vol. No. 10, Issue No. II, Apr-Jun

e-ISSN: 2249-4642, p-ISSN: 2454-4671

Table (1) Iraqi EFL College Students' opinions about using Kahoot Games in creating active learning

\begin{tabular}{|c|c|c|c|}
\hline & Components and Items & $\begin{array}{l}\text { Weighted } \\
\text { Average }\end{array}$ & $\begin{array}{l}\text { Weight } \\
\text { Percentage }\end{array}$ \\
\hline 1 & Kahoot boosts the interest of students in the lesson & 3.92 & $92.5 \%$ \\
\hline 2 & Kahoot adds to success of the lesson & 3.92 & $95 \%$ \\
\hline 3 & Kahoot brings about effective collaborative learning & 3.92 & $95 \%$ \\
\hline 4 & Kahoot covers Quizzes related to vocabulary, grammar and literature & 3.97 & $97.5 \%$ \\
\hline 5 & Activities included in Kahoot are more interesting & 4 & $100 \%$ \\
\hline 6 & Kahoot enhances the effectiveness of the lessons & 3.9 & $90 \%$ \\
\hline 7 & Kahoot allows unreserved self-expression & 4 & $100 \%$ \\
\hline 8 & Kahoot enables active learning & 3.97 & $97.5 \%$ \\
\hline 9 & Kahoot games motivate students & 3.95 & $95 \%$ \\
\hline 10 & Kahoot provides students with different perspectives & 4 & $100 \%$ \\
\hline 11 & Students are able to think more rapidly because of kahoot technique & 3.9 & $92.5 \%$ \\
\hline 12 & Learning via kahoot activities in the classroom is permenent & 3.95 & $95 \%$ \\
\hline 13 & Kahoot gives students the opportunity to deliver richer content & 3.87 & $90 \%$ \\
\hline 14 & Timely questions in Kahoot activities increase student excitement & 3.97 & $97.5 \%$ \\
\hline 15 & Use of poictures in kahoot application leads to better understanding & 3.9 & $90 \%$ \\
\hline 16 & Videos are part of kahoot that ensure attention of students & 3.87 & $92.5 \%$ \\
\hline 17 & Kahhot activities make esay learning possible & 3.87 & $92 \%$ \\
\hline 18 & Sharing activities via social media increases motivation & 3.95 & $95 \%$ \\
\hline 19 & The use of Kahoot in the classroom is encouraging and entertaining & 4 & $100 \%$ \\
\hline 20 & The active use of Kahoot builds courage and confidence & 3.92 & $92 \%$ \\
\hline
\end{tabular}


1 Kahoot increases interest in the lesson

2 Kahoot improves success

3 Using Kahoot makes for more effective collaborative learning

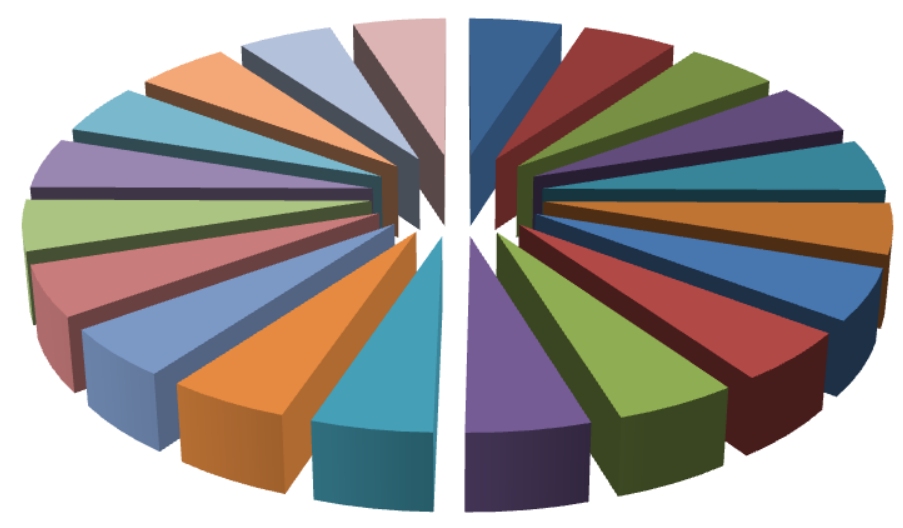

Graphic : (1) Iraqi EFL College Students' opinions about using using Kahoot Games in creating active learning

\section{RESULTS, CONCLUSIONS, RECOMMENDATIONS}

\subsection{Results Related to the Aim}

In order to identify and classify effectiveness of using Kahoot description in creating active learning.The descriptive statistics of participants' performance are shown in table 3.

Table (2) - Participants' performance

\begin{tabular}{|l|l|l|l|l|}
\hline & Mean & Median & Std. Deviation & Variance \\
\hline Q1 & 2.175 & 2.000 & 1.1068 & 1.225 \\
\hline Q2 & 3.0000 & 3.0000 & 0.75107 & 0.564 \\
\hline Q3 & 2.7500 & 3.0000 & 0.86972 & 0.756 \\
\hline Q4 & 2.6750 & 2.5000 & 0.94428 & 0.892 \\
\hline Q5 & 2.5750 & 2.5000 & 1.10680 & 1.225 \\
\hline Q6 & 2.5500 & 2.0000 & 0.93233 & 0.869 \\
\hline Q7 & 2.6500 & 3.0000 & 1.05125 & 1.105 \\
\hline Q8 & 2.8000 & 3.0000 & 0.88289 & 0.779 \\
\hline
\end{tabular}




\begin{tabular}{|l|l|l|l|l|}
\hline Q9 & 2.5000 & 2.5000 & 1.13228 & 1.282 \\
\hline Q10 & 2.6500 & 2.5000 & 0.86380 & 0.746 \\
\hline Q11 & 2.8000 & 3.0000 & 0.88289 & 0.779 \\
\hline Q12 & 2.5750 & 3.0000 & 1.12973 & 1.276 \\
\hline Q13 & 2.4750 & 2.5000 & 1.10911 & 1.230 \\
\hline Q14 & 2.5500 & 3.0000 & 0.63851 & 0.408 \\
\hline Q15 & 2.5750 & 3.0000 & 1.08338 & 1.174 \\
\hline Q16 & 2.7500 & 2.5000 & 0.95407 & 0.910 \\
\hline Q17 & 2.8500 & 3.0000 & 0.69982 & 0.490 \\
\hline Q18 & 2.7500 & 3.0000 & 0.92681 & 0.859 \\
\hline Q19 & 2.7000 & 3.0000 & 1.09075 & 1.190 \\
\hline Q20 & 2.8750 & 3.0000 & 1.06669 & 1.138 \\
\hline
\end{tabular}

Table (2) participants' performance Variance

Table (2) participants' performance Std. Deviation

- Table (2) participants' performance Median

Table (2) participants' performance Mean

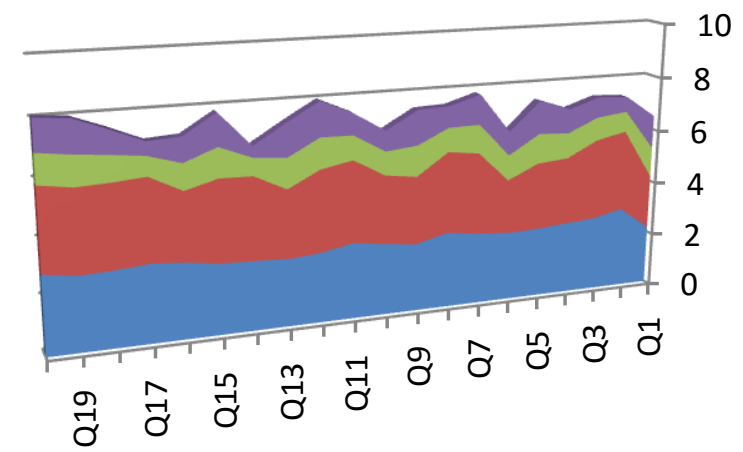

Graphic (2) : participants' performance

\subsection{Conclusion}

On the basis of the analysis of data given above, the following conclusions can be made:

1. Items 7, 10 and 19 which refer to (Kahoot allows for comfortable self-expression), (Question techniques in the activities performed by Kahoot provides the students with different perspective) and (The use of
Kahoot in the classroom encourages learners) gain the high effectiveness, the weighted mean is $100 \%$.

2. Items 6,13 and 15 which refer to (Kahoot increases the effectiveness of the lessons );(Kahoot gives students the opportunity to deliver richer content );and (Using pictures in Kahoot applications allows the user to more 
easily understand the content) indicate low effectiveness. The weighted mean is $90 \%$.

The students show interest towards using Kahoot application in creating active learning and give them a chance to discuss various topics with each other or to share opinions on current affairs. On the whole, kahoot techniques are effective, enjoyable, entertaining, engaging and active as well as interactive.

\subsection{Recommendations}

1. New methods of teaching creating active learning need to be implemented in our Colleges.

2. Instructors in colleges should be trained on using new techniques for teaching creating active learning, such as using Kahoot.

\section{REFERENCES}

Brown, H.D. (2003). Language Assessment Priciple and Classroom Practice. San Fransisco: Pearson Education

Byrne, R. (2013). Free technology for teachers: Kahoot! -create quizzesand surveys your students can answer on any device. Retrieve December12, 2015

Caglar(2017). Oyunla"tırılmı" Bir Ö!renme Ortamının Tasarlanması, Uygulanması ve Çe"itli De!i"kenlere Göre \$ncelenmesi.

Huckin, T. N., Haynes, M., \& Coady, J. (1993). Second Language

Harrocks, J. and Schannover, T. (1968). Measurement Teachers.

Comlumbus: Charles E. Merrill Publishing Company HayReading and Vocabulary Learning. New York, NY: Ablex Pub. Co.

Eble, R.L. (1972). Essentials of Educational Measurement. Englewood Cliffs N.J: Mishawaka, IN, U.S.A. Prentice - Hall, Inc.

Huckabee, I., \& Bissette, T. (2014). Learning made fun. Training Industry Magazine, 32- 35.

Gronlund, N.E. (1976). Measurement and Evaluation in Teaching. ( $3^{\text {rd }}$ ed.) New York: Macmillan publishing Co, Inc.
Larson, Jenifer. (2010). A Guide to Doing Statistics in Second Language Research Using SPSS. New York: Routledge

Latif, Mohammad Adnan. 2011. Research Methods on Language Learning. Malang: UM PRESS

Schwen, T. 1977. Professional scholarship in educational settings:Criteria for inquiring. AV Communication Reviews, 25, 35-79. Retrieved June 13, 2018, from https://en.wikipedia.org/wiki/Medi a_(communication)

Strommen, E.F. (1992). The Future of Classroom Learning, 24 (4), 466-

Sera, L., \& Wheeler, E. (2017). Game on: The gamification of the pharmacy classroom. Currents in Pharmacy Teaching and Learning, 9(1), 155-159. https://doi.org/10.1016/j.cptl. 2016.08.04

Werbach, K., \& Hunter, D. (2012). For the win: How game thinking can revolutionize your business. Wharton Digital Press. 